\title{
SISTEM INFORMASI KERJASAMA NASIONAL DAN INTERNASIONAL PADA UNIVERSITAS MURIA KUDUS
}

\author{
Ismawatul Maula ${ }^{1}$, Supriyono $^{2}$, Syafiul Muzid ${ }^{3}$ \\ ${ }^{123}$ Program Studi Sistem Informasi Fakultas Teknik Universitas Muria Kudus
}

\section{Article Info:}

Dikirim: 02 Desember 2020

Direvisi: 23 Desember 2020

Diterima: 30 Desember 2020

Tersedia Online: 31 Desember 2020

Penulis Korespondensi: Syafiul Muzid

Program Studi Sistem Informasi, Fakultas Teknik,

Universitas Muria Kudus,

Kudus, Indonesia

Email: syafiul.muzid@umk.ac.id
Abstrak: Salah satu cara membangun citra yang baik bagi perguruan tinggi adalah peningkatan kinerja kerjasama institusi baik secara nasional maupun internasional. Peningkatan kinerja ini dapat dilihat dari meningkatnya jumlah kerjasama dan pelaksanaan kerjasama yang sudah terjalin. Kantor Urusan Internasional Universitas Muria Kudus (KUI UMK) bertugas mengelola kerjasama baik ditingkat universitas maupun unit, serta memantau pelaksanaan dari kerjasama yang sudah terjalin. Namun terdapat kendala dalam melakukan kegiatan tersebut, yaitu data kerjasama yang masih terpisah disetiap unit dan tidak terekam dengan rapi, serta sering terlewatinya masa kontrak kerjasama dari batas waktunya. Oleh karena itu dibutuhkan suatu sistem untuk mendata, mengelola, memantau dan mengevaluasi kinerja kerjasama baik ditingkat unit maupun universitas serta memudahkan KUI UMK dalam memantau masa kontrak suatu kerjasama yang sudah terjalin.

Kata kunci: sistem monitoring; sistem manajemen kerjasama; monitoring kerjasama.

\begin{abstract}
Building good cooperation is one way to build an image for higher education. This performance improvement can be seen from the increase in the number of collaborations and collaborations that have been established. Kantor Urusan Internasional Universitas Muria Kudus (KUI UMK) is tasked with managing cooperation at both the university and unit levels, as well as monitoring the implementation of existing collaborations. However, there are obstacles in carrying out these activities, namely the cooperation data which is still separate in each unit and is not recorded properly, and the period of the cooperation contract period is often missed. Therefore, a system is needed to record, manage, monitor and evaluate the performance of cooperation at both the unit and university levels as well as to facilitate KUI UMK in monitoring the contract period of a cooperation that has been established.
\end{abstract}

Keywords: monitoring system; cooperation management system; cooperation monitoring. 


\section{PENDAHULUAN}

Kerjasama merupakan kesepakatan antara dua pihak yang bertujuan untuk mencapai keuntungan bersama. Dalam suatu lembaga maupun perusahaan kerjasama sudah menjadi kebutuhan bagi lembaga maupun perusahaan tersebut, karena dengan adanya kerjasama sebuah lembaga ataupun perusahaan dapat saling mendorong agar lebih berkembang. Sebuah kerjasama selalu dibatasi oleh masa berlaku atau periode waktu tertentu baik dalam jangka waktu pendek maupun jangka waktu panjang tergantung kesepakatan dari kedua belah pihak. Kegiatan dalam kerjasama akan berjalan lebih teratur dan sesuai harapan apabila memiliki rasa kepercayaan antar pihak.

Dalam sebuah perguruan tinggi, kerjasama merupakan salah satu poin yang penting dalam tingkat prestasi dan nama baik. Kerjasama tersebut bisa berupa kerjasama University to University (U2U), University to Government (U2G), maupun University to Business (U2B). Kerjasama antar instansi atau perguruan tinggi dilakukan untuk tujuan tertentu seperti program penelitian, pengabdian, kegiatan akademik mahasiswa, beasiswa dan program lainya yang saling memberikan keuantungan baik untuk kerjasama dalam maupun luar negeri [1]. Sedangkan program kerjasama antara perguruan tinggi dengan dunia industri seringkali menggunakan mixing model (cooperative-dual) yaitu kegiatan pembelajaran yang dilakukan diluar kampus (lingkungan industri) sehingga mahasiswa dapat mempraktekkan teori yang mereka peroleh dikelas [2]. Selain itu dengan adanya kerjasama dengan instansi luar maupun perguruan tinggi lain juga dapat memberikan keuntungan bagi perguruan tinggi yaitu meningkatkan akreditasi perguruan tinggi.

Kantor Urusan Internasional Universitas Muria Kudus (KUI UMK) merupakan unit yang bertugas untuk mengelola kerjasama baik di tingkat universitas maupun unit. KUI UMK telah menjalin banyak kerjasama dengan pihak luar baik kerjasama dalam negeri maupun luar negeri. Namun dalam pengelolaan kerjasama, KUI UMK memiliki beberapa masalah diantaranya: 1) sulitnya KUI UMK dalam mengetahui masa berlaku suatu kerjasama akan habis, 2) tidak terstruktur dan terdokumentasi dengan baik data kerjasama yang dimiliki antar tiap unit dan universitas menyebabkan kurangnya informasi mengenai kerjasama yang sedang terjalin, 3) belum adanya pendataan dari aktivitas Memorandum of Action (MoA) dari kerjasama yang sudah terjalin.

Berdasarkan masalah tersebut, maka diperlukan sebuah solusi sistem informasi yang dapat memudahkan KUI UMK dalam mengelola, mendata, memantau dan mengevaluasi kerjasama yang terjalin baik di tingkat universitas maupun unit, dan solusi sistem yang dapat memberikan notifikasi masa berlaku kerjasama yang akan habis serta pendataan MoA dari kerjasama yang sedang terjalin.

\section{METODOLOGI PENELITIAN}

Beberapa penelitian lain tentang sistem informasi kerjasama menjadi tinjauan pustaka dalam penelitian ini. Nugroho menjelaskan tentang pentingnya sistem kerjasama dan promosi dalam suatu perguruan tinggi. Sistem kerjasama dan promosi dikembangkan untuk memudahkan pihak perguruan tinggi dalam mengelola dan melaporkan data kerjasama dan promosi dengan baik [3]. Welda dan Minartiningtyas dalam penelitian tentang sistem informasi kerjasama dalam perguruan tinggi menjelaskan mengenai pengelolaan kerjasama berbasis sistem komputer dapat mempermudah pencatatan, pengarsipan, dan penyediaan informasi yang berhubungan dengan kerjasama semakin cepat [4].

Sugianto dan Aulia memberikan penjelasan tentang pengembangan sistem informasi kerjasama pada South East Asian Ministers of Education Organization Regional Open Learning Centre (SEAMOLEC). Selama ini proses pendataan kerjasama SEAMOLEC disimpan dalam file berupa excel/word yang terpisah dan pencatatan rencana kegiatan (work plan) dari masing-masing pihak juga masih terpisah sehingga meyulitkan dalam pengelolaannya. Hasil penelitiannya menyebutkan dengan sistem informasi kerjasama berbasis website mampu mempermudah penyusunan dokumen kerjasama, membantu mempercepat pencarian arsip dan memantau work plan [5]. Sedangkan Alfaruq dan Fahrurrozi menjelaskan mengenai sistem kerjasama pada perguruan tinggi. Dengan adanya sistem informasi kerjasama mampu memudahkan dalam pencatatan dokumen kerjasama, pencarian dokumen kerjasama yang lebih terorganisir sehingga meminimalisir terjadinya kehilangan dokumen dan memudahkan pencarian dokumen [6]. Marsuyitno dkk menjelaskan dengan adanya sistem informasi monitoring kerjasama dapat memberikan kemudahan dalam informasi atau pengingat dalam proses perpanjangan perjanjian kerja sama yang akan habis masa waktu kerja samanya [7].

Berdasarkan penelitian tersebut, bahwa penggunaan sistem informasi kerjasama sangat dibutuhkan saat ini untuk mempermudah perguruan tinggi dalam mengelola data kerjasama (Memorandum of Understanding/MoU) dan juga pelaksanaan dari kerjasama tersebut (Memorandum of Action/MoA). Pengguna sistem informasi tersebut juga mampu memantau masa berlaku suatu kerjasama sehingga dapat diketahui dengan mudah kapan berakhirnya suatu kerjasama yang sedang terjalin. Penelitian ini mengembangkan sistem informasi kerjasama untuk mengelola data kerjasama baik di tingkat nasional maupun internasional. Metode penelitian yang digunakan untuk mencapai tujuan penelitian adalah sebagai berikut:

\subsection{Metode Pengumpulan Data}

Metode yang digunakan dalam pengumpulan data agar data yang digunakan dalam penelitian akurat dan tepat adalah sebagai berikut:

a) Observasi, dilakukan dengan mengamati proses pendataan kerjasama, pendataan MoA di tingkat KUI UMK maupun di tingkat unit. 
b) Wawancara dengan pimpinan dan staf unit pengelola kerjasama yaitu Kantor Urusan Internasional Universitas Muria Kudus (KUI UMK).

c) Studi Pustaka terkait pengumpulan sumber data sekunder, yaitu sumber data yang didapatkan tidak secara langsung yang mendukung dalam pelaksanaan penelitian ini. Dalam hal ini studi pustaka terkait buku dan aturan tentang proses bisnis pengelolaan kerjasama di Universitas Muria Kudus.

\subsection{Metode Pengembangan Sistem}

Penelitian ini menggunakan metode pengembangan Waterfall, yaitu metode pengembangan sistem yang dilakukan antar satu fase ke fase yang lain secara berurutan dimana tiap tahapan tidak akan bisa dilaksanakan jika tahapan sebelumnya belum dilakukan [8]. Tahapan dalam metode tersebut adalah : 1) identifikasi masalah dan kebutuhan, 2) desain dan rancangan sistem baik alur proses, antarmuka dan basisdata yang akan dikembangkan, 3) tahap pengembangan program atau pengkodean, 4) pengujian sistem yang telah dikembangkan, dan 5) tahap penerapan sistem. Model ini merupakan model pengembangan sistem yang paling banyak digunakan dikarenakan tahapannya yang teratur setiap langkahnya [9].

\subsection{Analisa Sistem}

Berdasarkan analisa masalah yang telah dilakukan pada proses pengelolaan data kerjasama di KUI UMK. Berikut ini adalah beberapa aktor yang terlibat dalam proses tersebut:

a) KUI atau pengelola Kantor Urusan Internasional bertugas mengelola data unit, pendataan mitra, mengelola usulan kerjasama, pendataan MoU dan MoA.

b) Wakil Rektor 4 bertugas memantau usulan kerjasama, data MoU dan MoA serta menyetujui permohonan kerjasama dari pihak luar (eksternal).

c) Unit adalah pengelola setiap unit didalam Universitas Muria Kudus yang terdiri dari fakultas, lembaga, badan dan program studi.

d) sedangkan Mitra adalah pihak luar (eksternal) yang mengajukan permohonan kerjasama dengan Universitas Muria Kudus.

Tahapan analisa masalah dan sistem juga menghasilkan beberapa proses bisnis yang dilakukan oleh aktoraktor tersebut sebagai berikut :

a) KUI bertugas mengelola data pengguna sistem (user) serta data unit.

b) Unit dapat mengajukan usulan kerjasama kepada KUI yang tentunya akan diverifikasi oleh KUI dan disetujui oleh Wakil Rektor 4 melalui konfirmasi usulan.

c) Data mitra untuk kerjasama yang sudah berjalan selama ini didata oleh KUI dan Unit terkait ke dalam sistem.

d) KUI dan Unit dapat mengelola data MoU dan MoA ke dalam sistem.

e) Mitra dari pihak luar (eksternal) yang ingin menjalin kerjasama dengan Universitas Muria Kudus dapat melakukan registrasi terlebih dahulu, kemudian mengajukan usulan permohonan kerjasama.

f) Usulan kerjasama dari pihak luar diseleksi terlebih dahulu oleh Wakil Rektor 4.

\section{HASIL DAN PEMBAHASAN}

\subsection{Perancangan Sistem}

Hasil analisa sistem tersebut kemudian dilanjutkan kedalam tahap perancangan sistem menggunakan diagram perancangan berorientasi obyek yaitu diagram Unified Modelling Language (UML). Unified Modeling Language $(U M L)$ adalah suatu bahasa permodelan untuk membangun perangkat lunak yang dibangun dengan menggunakan teknik pemrograman berorientasi objek. Desain sistem terdiri atas perancangan antarmuka, estetika, konten, navigasi, arsitektur, komponen. Rancang bangun dalam penelitian ini menggunakan perancangan berorientasi objek (UML) [10].

Tahap perancangan sistem menghasilkan beberapa diagram yang digunakan dalam pengembangan sistem, diantaranya yaitu diagram usecase, diagram class, diagram sequence, diagram activity dan diagram state. Diagram usecase merupakan diagram yang mendeskripsikan interaksi antara satu atau lebih aktor dengan sistem informasi yang akan dibuat [11]. Diagram usecase yang digunakan dalam penelitian ini terdiri dari 2 (dua) jenis diagram yaitu diagram business usecase dan diagram system usecase.

Diagram business usecase, yaitu diagram yang menjelaskan mengenai hubungan antara aktor-aktor dalam proses bisnis baik di dalam maupun di luar organisasi tersebut. Gambar 1 menjelaskan tentang diagram business usecase yang dihasilkan pada tahap perancangan ini. Terdapat 5 (lima) aktor yang terlibat dalam proses bisnis pengelolaan data kerjasama di Universitas Muria Kudus, yaitu KUI, Wakil Rektor 4, Unit, Mitra dan Rektor. Namun pada proses bisnis tersebut, Rektor berperan sebagai business actor yaitu aktor yang terlibat di dalam proses bisnis namun berasal dari luar domain proses bisnis sehingga tidak terlibat didalam sistem yang dikembangkan. Diagram business usecase menggambarkan alur proses bisnis baik proses bisnis manual maupun proses bisnis yang masuk ke dalam sistem yang dikembangkan. Gambar 1 menjelaskan tentang diagram business 
usecase yang terdiri dari 13 (tiga belas) akktivitas usecase. Namun ada beberapa aktivitas usecase yang hanya muncul dalam diagram business usecase tapi tidak masuk ke dalam diagram system usecase yaitu pembuatan undangan, diskusi draft kerjasama, pengecekan masa berlaku. Hal ini dikarenakan aktivitas tersebut dilakukan secara manual diluar sistem.

Pada Gambar 2 menunjukkan gambar diagram system usecase yang digunakan dalam pengembangan Sistem Informasi Kerjasama Nasional dan Internasional Universitas Muria Kudus. Aktor yang terlibat dalam diagram usecase adalah sebanyak 4 (empat) aktor yaitu KUI, Wakil Rektor 4, Unit dan Mitra. Setiap aktor tersebut memilik hak akses yang berbebda-beda sesuai dengan proses bisnis yang dilakukan oleh masing-masing aktor tersebut. Gambar 2 juga menampilkan sebanyak 10 (sepuluh) aktivitas usecase. Setiap usecase dapat diakses oleh aktor sesuai dengan hak akses yang dimilikinya. Aktor KUI adalah aktor yang mewakili dari Kantor Urusan Internasional Universitas Muria Kudus (KUI UMK). Aktor KUI dapat mengakses beberapa usecase diantaranya yaitu mengelola data user, mengelola data unit, mengelola usulan kerjasama (dari unit), mengelola konfirmasi usulan, pendataan mitra, pendataan MoU, pendataan MoA. Aktor Wakil Rektor 4 memilik hak akses untuk melihat usulan kerjasama (dari unit), melakukan konfirmasi usulan, melihat data MoU, melihat data MoA, melihat permohonan kerjasama dari pihak eksternal, serta melakukan seleksi terhadap permohonan tersebut. Sedangkan aktor Unit bertugas mengajukan pendataan mitra, usulan kerjasama, melihat konfirmasi usulan, pendataan MoU, dan pendataan MoA. Aktor Mitra merupakan pihak eksternal yang ingin mengajukan permohonan kerjasama dengan Universitas Muria Kudus. Aktor Mitra memiliki hak akses untuk melakukan registrasi mitra, mengajukan permohonan kerjasama dan melihat hasil seleksi ajuan permohonan kerjasamanya apakah diterima atau ditolak.

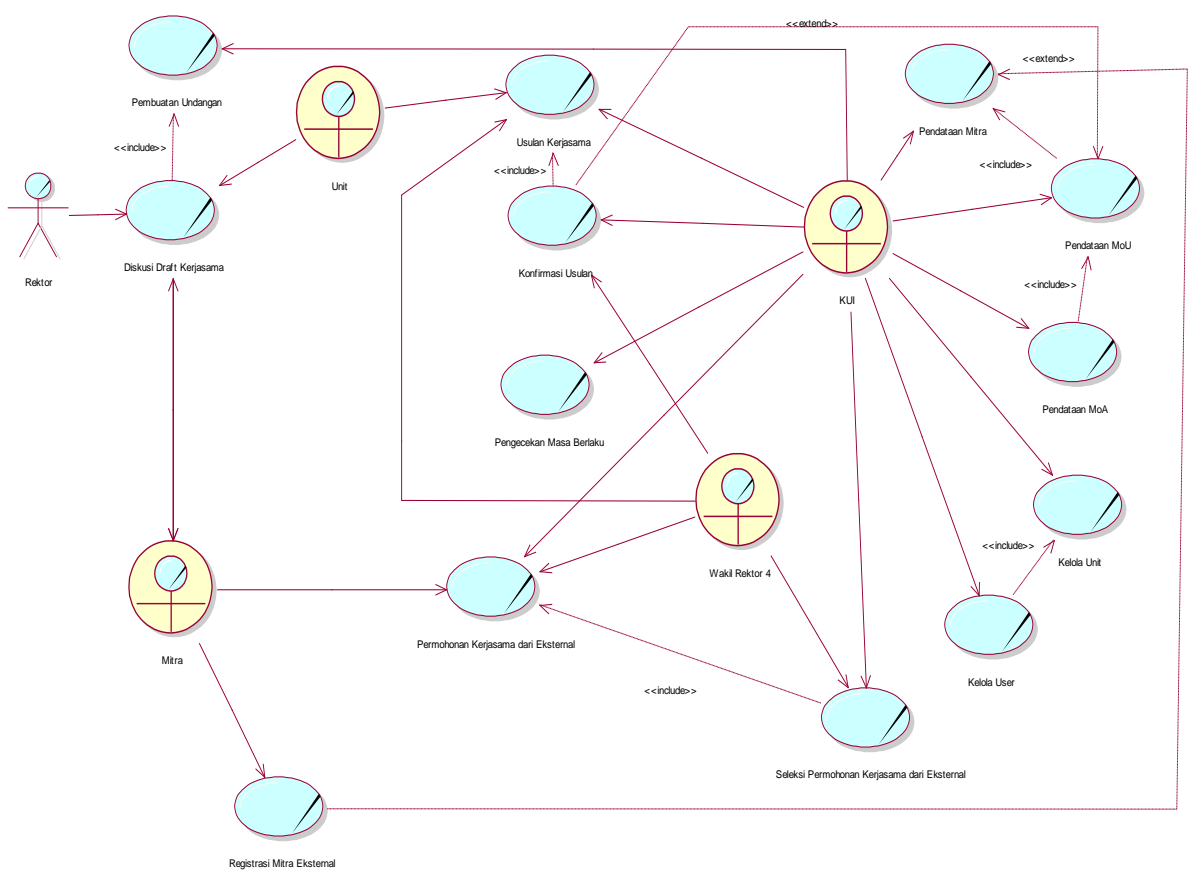

Gambar 1. Diagram Business Usecase Sistem Informasi Kerjasama Nasional dan Internasional

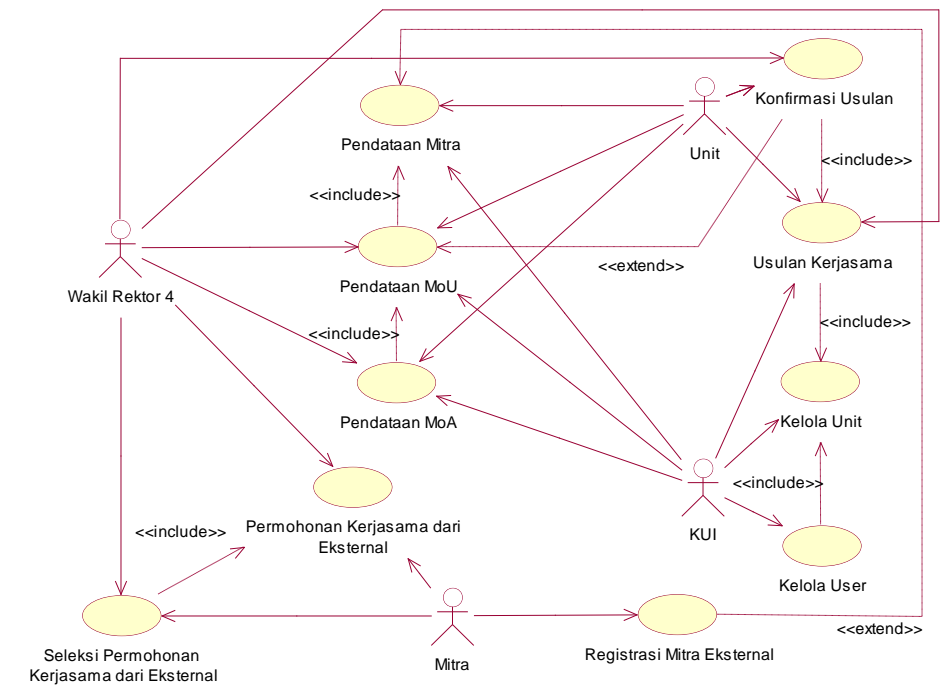

Gambar 2. Diagram System Usecase Sistem Informasi Kerjasama Nasional dan Internasional 


\subsection{Perancangan Basisdata}

Tahap perancangan sistem menghasilkan rancangan alur sistem, rancangan antarmuka dan rancangan basisdata. Basisdata yang digunakan dalam Sistem Informasi Kerjasama Nasional dan Internasional Universitas Muria Kudus terdiri dari 13 (tiga belas) tabel yang saling berelasi seperti pada Gambar 3.

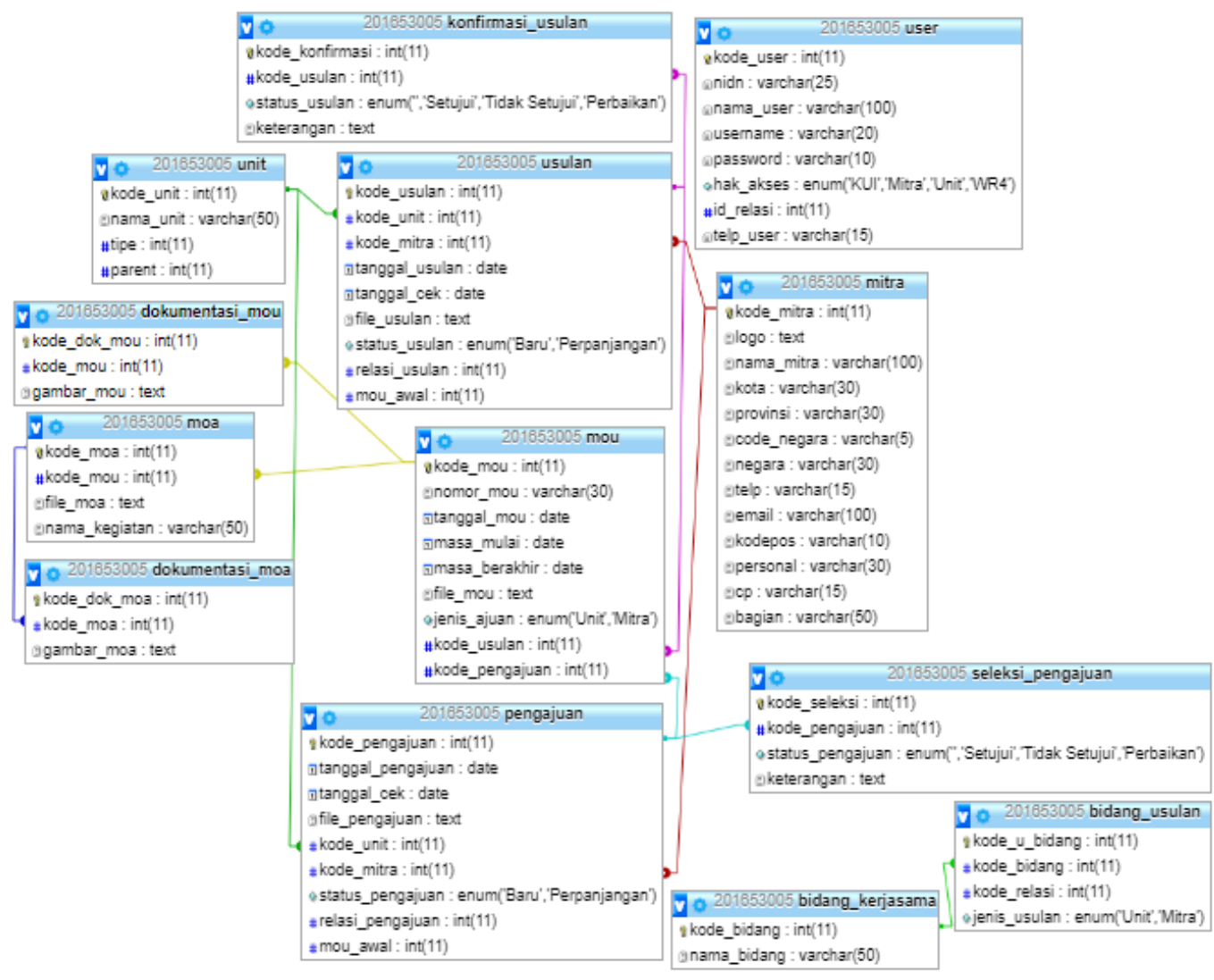

Gambar 3. Diagram Relasi Tabel Sistem Informasi Kerjasama Nasional dan Internasional

\subsection{Hasil Sistem}

Pada tahap ini, dilakukan pengembangan Sistem Informasi Kerjasama Nasional dan Internasional Universitas Muria Kudus setelah tahapan analisa dan perancangan dilakukan. Pengembangan dilakukan menggunakan Bahasa pemrogram PHP dan basisdata MySQL. Berikut ini adalah antarmuka hasil pengembangan sistem yang telah dilakukan. Pada Gambar 4 menunjukkan antarmuka halaman utama ketika sistem diakses/dibuka.
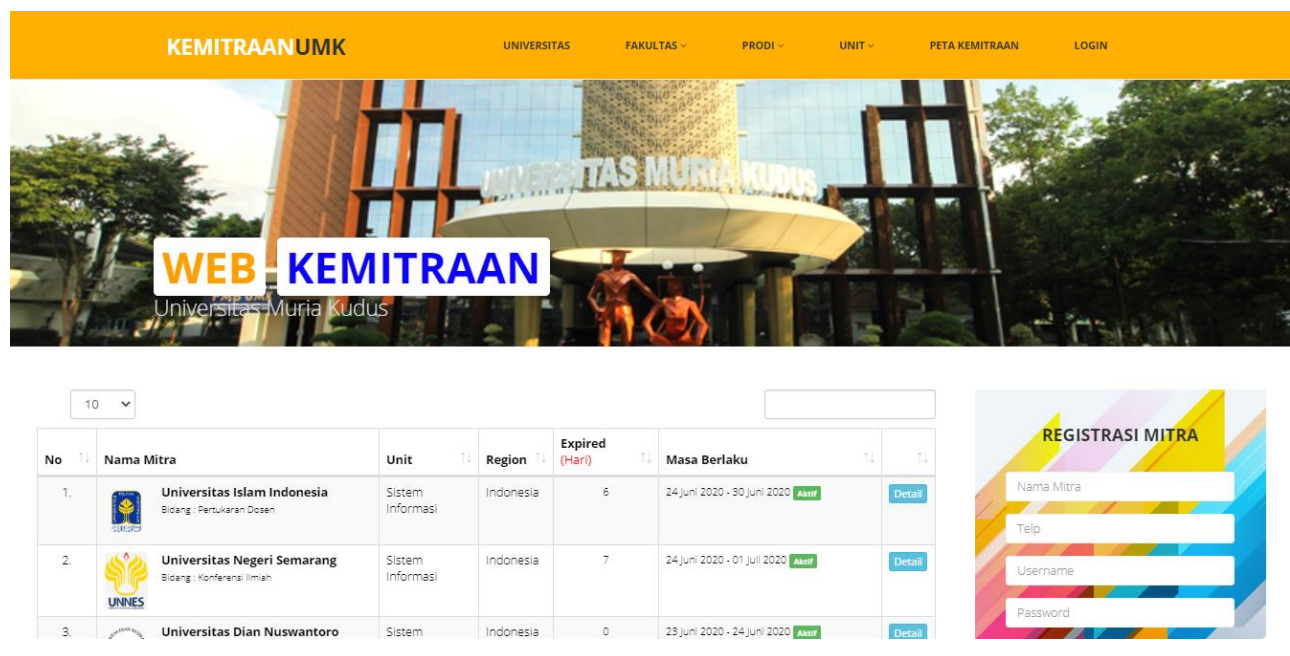

Gambar 4. Antarmuka Halaman Utama Sistem Informasi Kerjasama Nasional dan Internasional 
Berdasarkan proses bisnis yang telah dianalisa, sebuah kerjasama diawali dengan proses pengajuan usulan kerjasama baik dari pihak internal maupun eksternal. Pihak internal berarti KUI dan unit yang ada di Universitas Muria Kudus. Sedangkan pihak eksternal adalah mitra dari luar perguruan tinggi yang ingin mengajukan kerjasama. Proses pengajuan usulan kerjasama dari pihak internal dapat dilihat pada Gambar 5. Pada Gambar 5 menunjukkan antarmuka daftar usulan yang telah diajukan kepada KUI UMK sedangkan untuk menambah ajuan dapat menekan tombol Tambah.

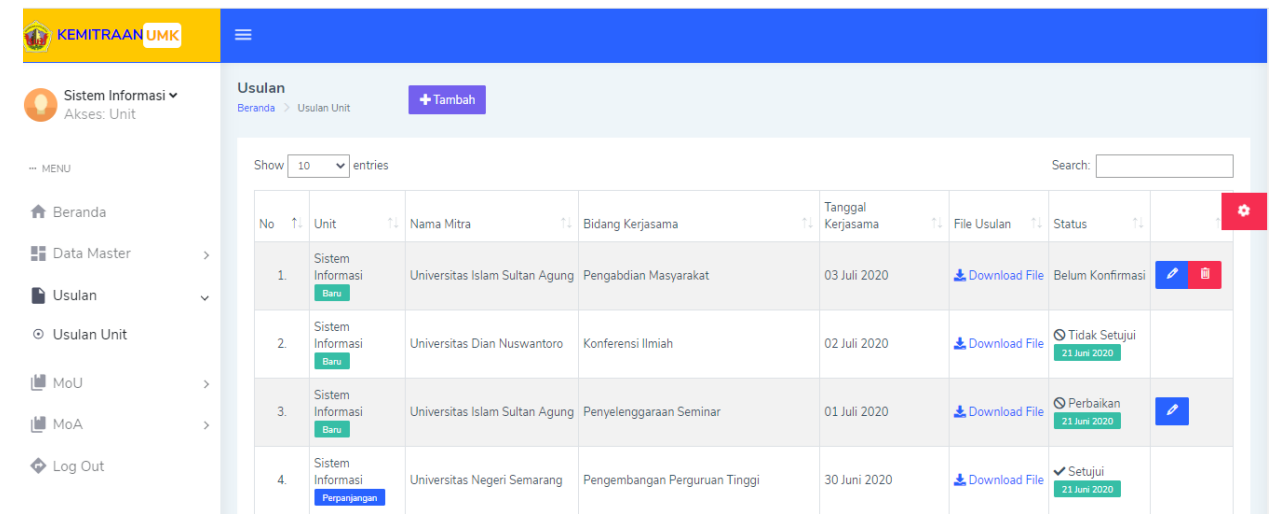

Gambar 5. Antarmuka Daftar Usulan yang diajukan kepada KUI UMK

Usulan yang telah diajukan kemudian diverifikasi oleh KUI dan dikonfirmasi atau disetujui oleh Wakil Rektor 4. Setiap usulan yang diajukan bisa disetujui ataupun ditolak. Gambar 6 menunjukkan antarmuka halaman konfirmasi yang dilakukan oleh Wakil Rektor 4 terhadap suatu ajuan usulan kerjasama.

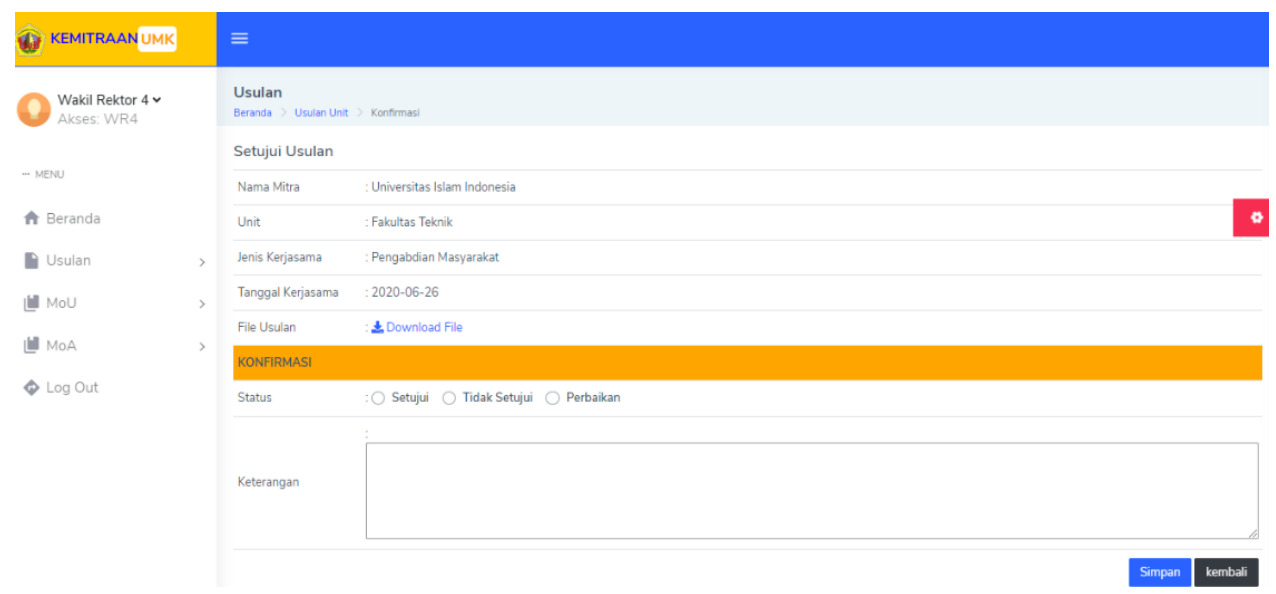

\section{Gambar 6. Antarmuka Konfirmasi Usulan Kerjasama Baru}

Data kerjasama meliputi MoU maupun MoA yang sudah ada dapat dikelola melalui menu MoU dan menu MoA. Pada Gambar 7 dapat dilihat antarmuka untuk menambahkan data MoU dan dokumennya serta masa berlaku MoU tersebut. Sedangkan Gambar 8 menunjukkan antarmuka untuk mengelola dokumen MoA terkait dengan MoU yang sudah terjalin.

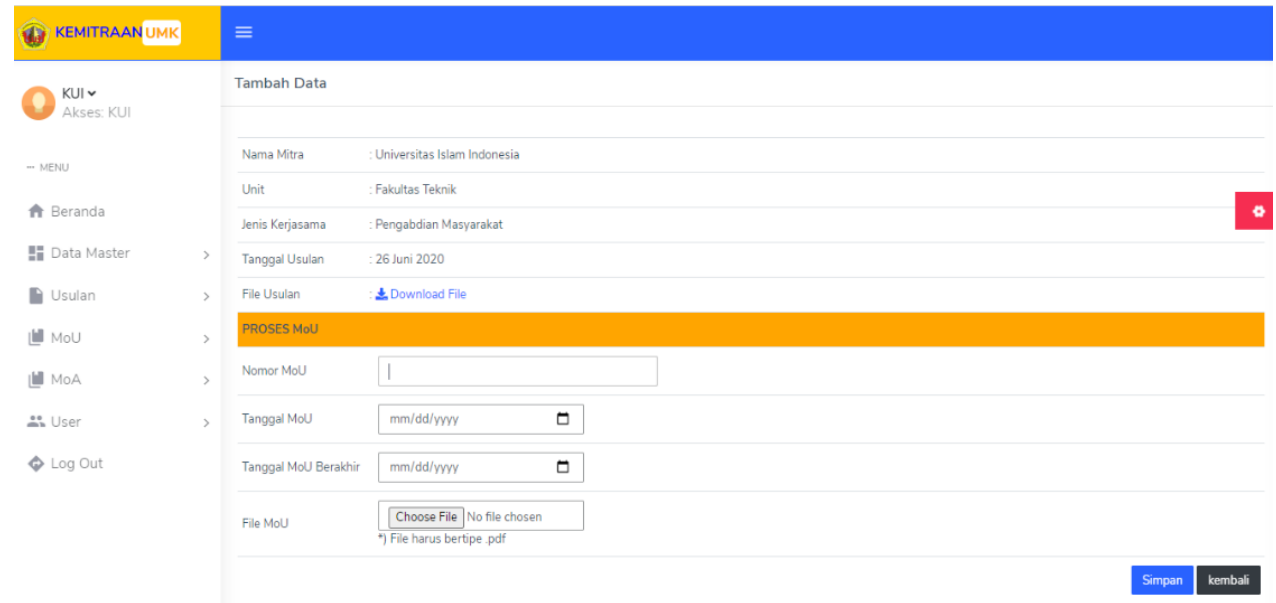

Gambar 7. Antarmuka Tambah Data MoU 


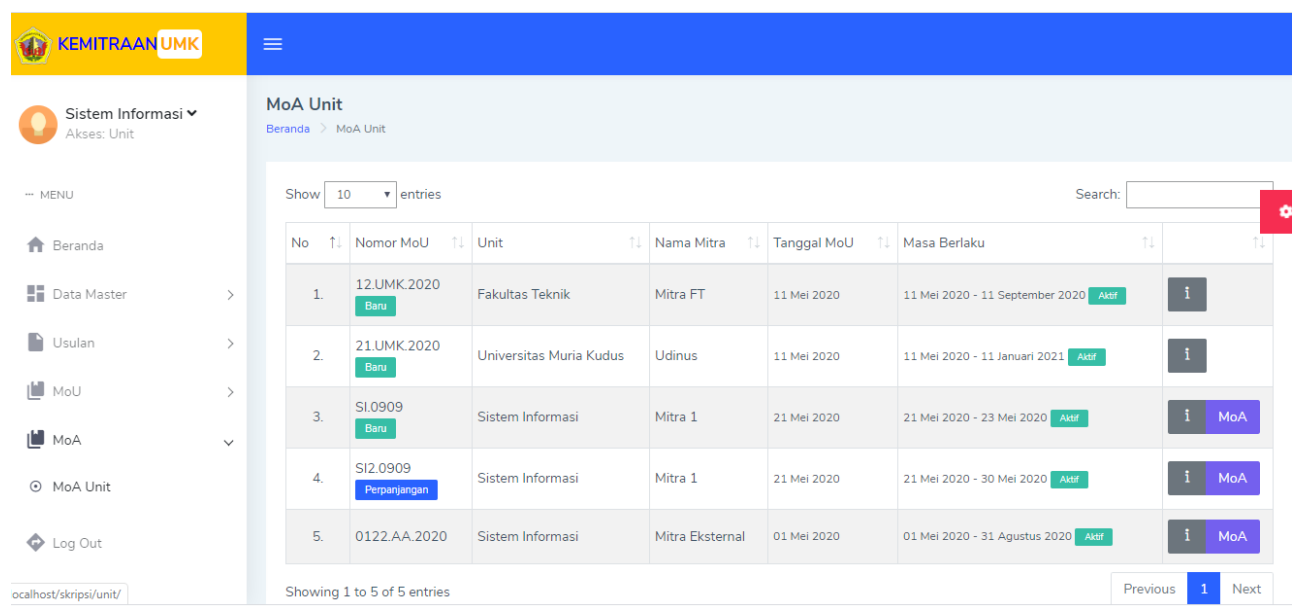

Gambar 8. Antarmuka Data MoA dari daftar MoU yang sudah Terjalin

Data kerjasama yang masa berlakunya akan habis dapat dilihat dari informasi pada menu MoU. Jika masa berlaku suatu kerjasama akan habis maka otomatis muncul tombol Perpanjangan seperti pada Gambar 9 . Pengajuan perpanjangan dapat diusulkan oleh unit maupun oleh KUI sebagai pengelola kerjasama. Perpanjangan yang diusulkan akan diproses oleh KUI dengan mengunggah dokumen MoU yang baru dengan masa berlaku yang baru. Antarmuka pengajuan perpanjangan MoU dapat dilihat pada Gambar 10.

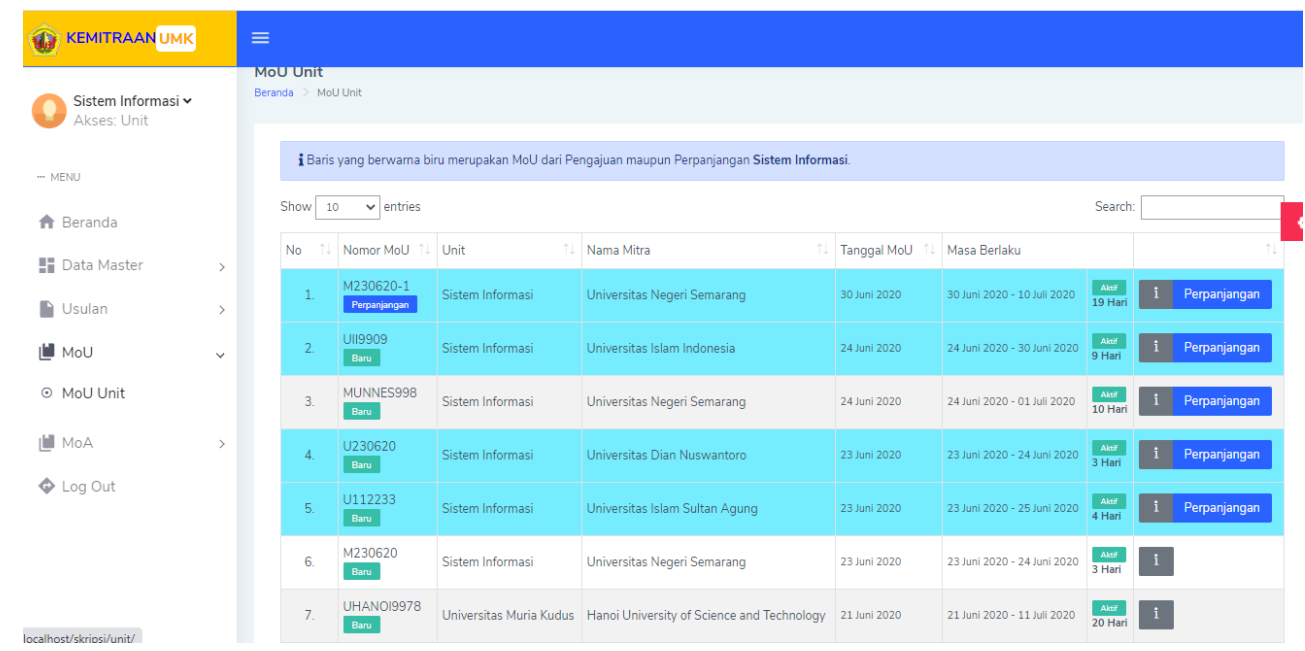

Gambar 9. Antarmuka daftar MoU dan Informasi Perpanjangan Kerjasama yang akan Habis Masa Berlakunya

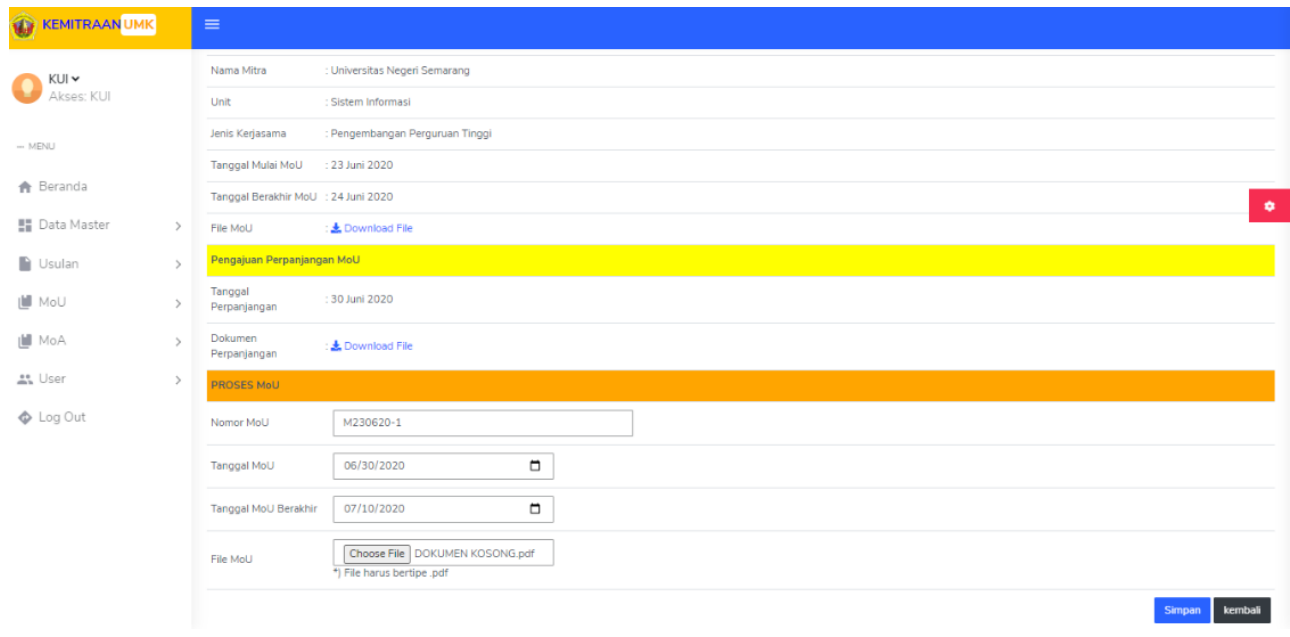

Gambar 10. Antarmuka Menu Pengajuan Perpanjangan MoU 


\section{KESIMPULAN}

\subsection{Kesimpulan}

Berdasarkan dari hasil penelitian Sistem Informasi Kerjasama Nasional dan internasional Universitas Muria Kudus maka dapat diambil beberapa kesimpulan sebagai berikut:

a) Sistem informasi ini memudahkan Kantor Urusan Internasional Universitas Muria Kudus (KUI UMK) dalam mengelola data kerjasama, usulan kerjasama dan perpanjangan kerjasama.

b) Sistem ini juga memberikan informasi masa berlaku dari suatu kerjasama sehingga dapat segera dilakukan perpanjangan kerjasama tersebut.

c) Dengan sistem ini, pihak eksternal dapat dengan mudah dalam mengajukan permohonan kerjasama dan memudahkan Wakil Rektor 4 dalam melakukan seleksi permohonan kerjasama.

\subsection{Saran}

Penelitian ini masih banyak memiliki kekurangan sehingga perlu dilakukan penelitian lebih lanjut. Berikut beberapa saran untuk penelitian selanjutnya:

a) Sistem yang dikembangkan masih berbasis web, diharapkan untuk kemudahan penggunaan dan portability adanya pengembangan sistem berbasis mobile.

b) Diharapkan adanya fitur notifikasi masa berlaku kerjasama yang akan habis sehingga memudahkan bagi KUI maupun unit untuk melakukan perpanjangan kerjasama.

c) Untuk memudahkan informasi peningkatan kerjasama, diharapkan adanya fitur pengelompokkan daftar kerjasama menggunakan peta penyebaran baik secara nasional maupun internasional.

\section{DAFTAR PUSTAKA}

[1] Sidik, R. 2014. "Model Sistem Informasi Kolaborasi Pada Kerjasama Antar Universitas (University To University)". Jurnal Teknologi dan Informasi (JATI). volume 4. no. 2, pp. 61-70.

[2] Sugiyanti, D. Nurhadi, D. 2013. "Implementasi Program Kerjasama antara Perguruan Tinggi dengan Dunia Industri”. Jurnal PHENOMENON. volume 1. no. 1, pp. 63-77.

[3] Nugroho, A.S.A. (2014). "Pembangunan Sistem Informasi Kerjasama dan Promosi Berbasis Web (Studi Kasus Universitas Atmajaya Yogyakarta)". Skripsi. Program Studi Teknik Informatika Fakultas Teknologi Industri Universitas Atma Jaya Yogyakarta, Yogyakarta.

[4] Welda. Minartiningtyas, B.A. 2017. "Sistem Informasi Pengelolaan Kerjasama Bidang Humas pada STMIK STIKOM Indonesia”. Jurnal SISFOKOM. volume 6. no. 2, pp. 86-92.

[5] Sugianto, C.A. Aulia, I. 2017. "Pengembangan Sistem Informasi Kerjasama Berbasis Web Studi Kasus : pada SEAMOLEC". Jurnal RESTI. volume 1. no. 2, pp. 137-145.

[6] Alfaruq, A. Fahrurrozi, I. (2017). "Sistem Informasi Kerjasama (SIKERMA) Studi Kasus : Sekolah Vokasi Universitas Gadjah Mada”. Tugas Akhir. D3 Ilmu Komputer dan Sistem Informasi Sekolah Vokasi Universitas Gadjah Mada, Yogyakarta.

[7] Marsuyitno. dkk. 2020. "Sistem Informasi Monitoring Perjanjian Kerja Sama Berbasis Web pada PT Dayamitra Telekomunikasi Jakarta”. Jurnal Media Informatika Budidarma. volume 4. no. 1, pp. 193-200.

[8] Sommerville, I. (2011). Software Engineering (9th Edition). USA : Pearson Education.

[9] Pressman. R. (2002). Software Engineering : Practical Approach, New York : Wembley-Hills.

[10] Podeswa, H. (2006). UMLfor the IT Business Analyst: A Practical Guide to Object-Oriented Requirements Gathering. Boston: Thomson Course Technology PTR.

[11] Sukamto, R. A. Shalahuddin, M. (2016). Rekayasa Perangkat Lunak Terstruktur dan Berorientasi Objek. Bandung: Informatika. 